\title{
Bilateral Mixed Germ Cell Tumour in an Adolescent Girl with Premature Ovarian Failure
}

\author{
Priyankur Roy1*, Bivas Biswas ${ }^{2}$, Suman Paul ${ }^{3}$, Lisa Choudhrie ${ }^{4}$, Ruby Jose ${ }^{5}$ \\ ${ }^{1}$ Department of Obstetrics and Gynaecology, JSS Medical College, Mysore, India \\ ${ }^{2}$ Department of Obstetrics and Gynaecology, King's Mill Hospital, Sutton in Ashfield, Nottinghamshire, UK \\ ${ }^{3}$ Lisie Hospital, Cochin, India \\ ${ }^{4}$ Department of General Pathology, Christian Medical College \& Hospital (CMCH), Vellore, India \\ ${ }^{5}$ Department of Obstetrics \& Gynaecology, Christian Medical College \& Hospital (CMCH), Vellore, India \\ Email: * priyankurroy@hotmail.com, bivasbiswas93@gmail.com, sumanpaul77@yahoo.com, \\ lisachoudhrie@gmail.com, og2@cmcvellore.ac.in
}

Received 25 July 2014; revised 20 August 2014; accepted 13 September 2014

Copyright (C) 2014 by authors and Scientific Research Publishing Inc.

This work is licensed under the Creative Commons Attribution International License (CC BY).

http://creativecommons.org/licenses/by/4.0/

C. (i) Open Access

\begin{abstract}
Germ cell tumours (GCTs) of the ovary are rare, comprising approximately $20 \%$ of all ovarian tumors with the malignant variant accounting for less than $5 \%$ of all ovarian neoplasms. Malignant mixed germ cell tumours are rarer still with dysgerminoma \& yolk sac tumour being the most common components with three component variants being categorised in the rarest of rare varieties. Bilateral dysgerminomas occur in $15 \%$ of germ cell neoplasms but rarely present with premature ovarian failure. We present the case of an adolescent girl with a short history of abdominal pain and distension with amenorrhoea for a year. Clinical and radio ogical examination revealed a pelvic/adnexal mass with elevation of tumour markers and she had to undergo a staging laparotomy with bilateral salpingo-oophorectomy. Histopatholgy examination was reported as malignant mixed germ cell tumour of left ovary, predominantly with immature teratoma and minor components of yolk-sac tumour and dysgerminoma and right ovary with dysgerminoma. In view of mixed germ cell disease, she was planned for adjuvant chemotherapy.
\end{abstract}

\section{Keywords}

Mixed Germ Cell Tumour, Teratoma, Dysgerminoma, Yolk Sac Tumour, Premature Ovarian Failure

\footnotetext{
${ }^{*}$ Corresponding author.
}

How to cite this paper: Roy, P., Biswas, B., Paul, S., Choudhrie, L. and Jose, R. (2014) Bilateral Mixed Germ Cell Tumour in an Adolescent Girl with Premature Ovarian Failure. Open Journal of Obstetrics and Gynecology, 4, 805-808. 


\section{Introduction}

A germ cell tumor (GCT) is a neoplasm derived from germ cells inside the gonads [ovary or testis] and can be cancerous or non-cancerous. Approximately $3 \%-5 \%$ of ovarian GCTs are malignant [1] and frequently affect adolescent women of the reproductive age group.

The World Health Organization has classified germ cell tumours as dysgerminoma, endodermal sinus tumour, embryonal carcinoma, polyembryoma, choriocarcinoma, teratomas (immature, mature, monodermal), mixed and gonadoblastoma [2]. Orientals have a higher proportion of non-dysgerminomatous malignant ovarian germ cell tumours when compared to reports in western literature [3].

\section{Case History}

An adolescent girl attained menarche aged 14 and had regular cycles for 1 year and initially presented with secondary amenorrhoea. A complete work up showed elevated FSH levels and a normal karyotype. With a diagnosis of premature ovarian failure the patient was started on hormone replacement which she took for 3 cycles during which the periods regularised and then the patient discontinued therapy on her own and was lost to follow up. The patient presented again aged 18 years with abdominal pain and distension for 3 weeks and had been amenorrhoeic for about 1 year.

On examination, the patient was emaciated with a BMI of $14 \mathrm{~kg} / \mathrm{m}^{2}$. There was no lymphadenopathy and the secondary sexual characters were poorly developed. Per-abdominal examination revealed a firm, mass arising in the lower abdomen consistent with a 22-week gravid uterus. This had restricted mobility and there was no free fluid in the abdomen. Ultrasonographic examination revealed a $15 \times 15 \mathrm{~cm}$ solid mass in the pelvis, with colour flow in malignancy range with a pulsatility index of 0.8 and a resistance index of 0.5 . The uterus was separately seen from the tumour and there was no free fluid in the abdomen or pelvis. Serum B-HCG, LDH and AFP were all found to be elevated. Thus with a working diagnosis of mixed germ cell malignancy she was planned for a staging laparotomy.

Intra-operatively there was $50 \mathrm{ml}$ of haemorrhagic ascites; the left ovary was completely replaced by a $25 \times$ $20 \mathrm{~cm}$ tumour, the capsule of which had ruptured. The right ovary was also completely replaced with a solid tumour of size $8 \times 8 \mathrm{~cm}$ with no normal ovarian tissue. There was no evidence of metastasis or enlarged lymph nodes. Bilateral salpingo-oophorectomy was done. Her post-operative period was uneventful (Figure 1, Figure 2).

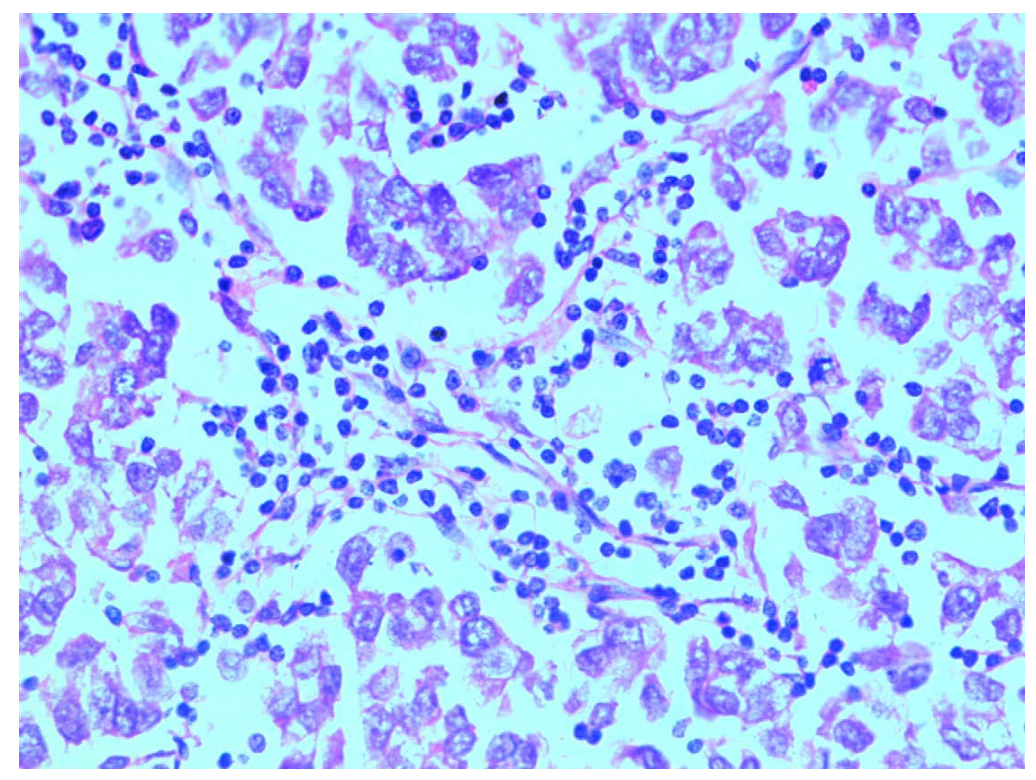

Figure 1. Photomicrograph of dysgerminoma, Haematoxylin-Eosin 40×. Nests of tumour cells intersected by fibrous septae containing numerous lymphocytes. The tumour cells are polygonal with distinct cell membranes and abundant granular to clear cytoplasm. 


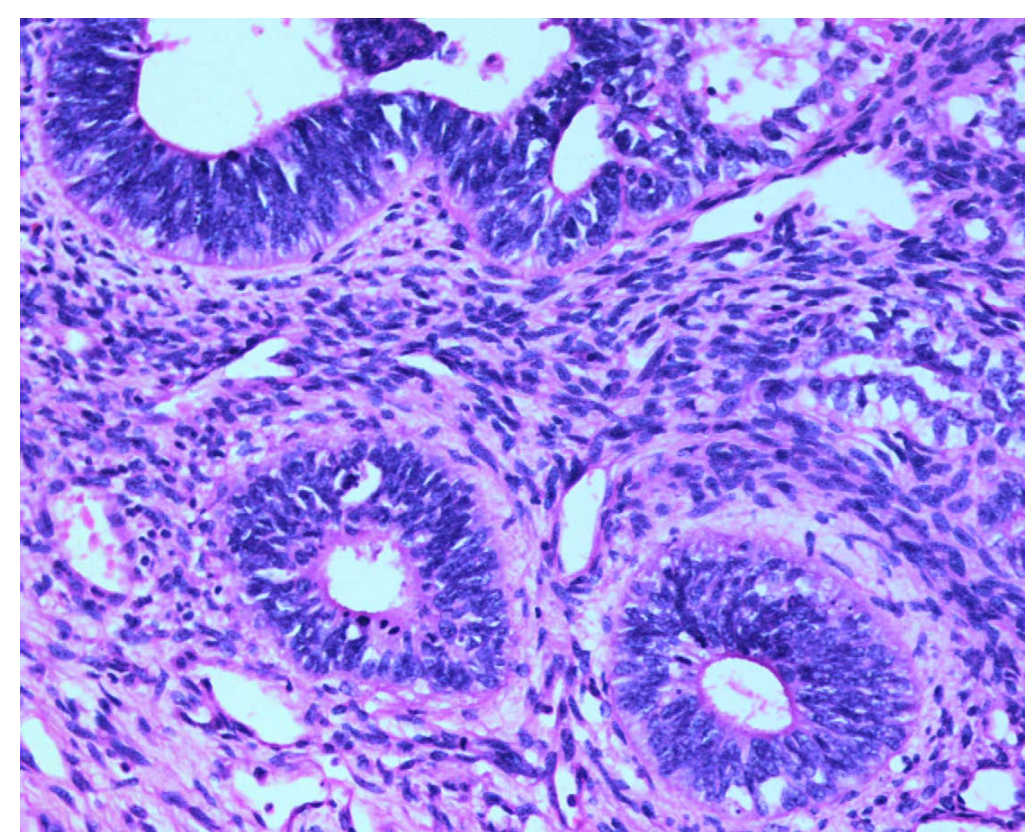

Figure 2. Photomicrograph of immature teratoma, Haematoxylin-Eosin 20×. Immature neuroepithelium composed of tubules lined by columnar embryonal cells with stratified hyperchromatic nuclei set in a loosely cellular stroma.

Histopathology was reported as malignant mixed germ cell tumour of left ovary with predominantly immature teratoma and minor components of yolk-sac tumour and dysgerminoma and right ovary with dysgerminoma. Ascitic fluid cytology showed scanty atypical cells. In view of mixed germ cell disease, stage IC (FIGO classification), she was planned for adjuvant chemotherapy with bleomycin, etoposide and cisplatin regimen. After completion of chemotherapy [6 cycles] she has been planned on regular follow up and hormone replacement therapy till the age of 45 years.

\section{Discussion}

Germ cell tumours are important because they affect women of reproductive age. Dysgerminoma is the most common germ cell tumour, accounting for $50 \%$ of cases and occurs predominantly in girls and young women [4]. It represents the female counterpart of testicular seminoma and is unique among malignant ovarian germ cell tumors for its bilaterality and exquisite radiosensitivity.

Yolk sac tumour (also known as endodermal sinus tumour) accounting for $20 \%$ of all cases is the next commonest with an average age of 19 years at presentation. Embryonal carcinoma of the ovary is an extremely rare tumour and represents only about 4 percent of malignant ovarian germ cell tumours [1]. It is distinguished from a choriocarcinoma by the absence of syncytiotrophoblastic and cytotrophoblastic cells. Pure nongestational choriocarcinoma of the ovary is extremely rare, as it is nearly always mixed with other germ cell elements [5] as manifested in our case. Histologically, it has the same appearance as gestational choriocarcinoma which metastasizes to the ovaries [1]. Mixed germ-cell tumours of the ovary contain 2 or more variants and the commonest is a combination dysgerminoma with a teratoma.

Typically, germ cells are encapsulated at birth within the primordial follicle. If they somehow escape encapsulation, cell death usually occurs. If however the germ cells survive, rapid growth ensues because no cellular contexts can provide normal contact inhibition [5], hence GCT formation. Unlike epithelial ovarian tumours, a preponderance (75\% - 80\%) of patients presents as stage I cancers and can therefore be treated by surgical resection alone usually with a unilateral salpingo-oophorectomy. This is preferred when attempting to preserve fertility. However, diligent and robust follow-up care, with serial pelvic examinations and tumor markers is mandatory if resection is the only treatment modality. Bilateral disease is a justification for bilateral salpingooophorectomy [6], especially if there is no residual ovarian tissue to salvage as experienced in our case. A total abdominal hysterectomy is not mandatory but may be performed concurrently if patients are no longer interested 
in bearing children [2]. We have preserved the uterus in our patient to give her the chance for future fertility treatment on a donor programme.

Radiation therapy was the traditional post-operative treatment for patients with metastasis giving excellent cure rates albeit producing ovarian failure. Nowadays patients with metastatic disease are treated with the chemotherapy combination of bleomycin, etoposide, and cisplatin (BEP) [7] which is equally effective as radiation while preserving fertility in these young and often nulligravid patients [8].

Bilateral dysgerminomas are known to occur in $15 \%$ of patients but very rarely present with premature ovarian failure. This fact along with the presence of 3 different variants of germ cell neoplasm in one ovary makes this case unique and worth reporting.

\section{References}

[1] Kurman, R.J. and Norris, H.J. (1977) Malignant Germ Cell Tumors of the Ovary. Human Pathology, 8, 551-564. http://dx.doi.org/10.1016/S0046-8177(77)80115-9

[2] Gershenson, D.M. (1993) Update on Malignant Ovarian Germ Cell Tumors. Cancer, 71, 1581-1590. http://dx.doi.org/10.1002/cncr.2820710425

[3] Lim, F.K., Chanrachakul, B., Chong, S.M., et al. (1998) Malignant Ovarian Germ Cell Tumours: Experience in the National University Hospital of Singapore. Annals Academy of Medicine Singapore, 27, 657-661.

[4] De Palo, G., Pilotti, S., Kenda, R., et al. (1982) Natural History of Dysgerminoma. American Journal of Obstetrics Gynecology, 143, 799-807.

[5] Serov, S.F., Scully, R.E. and Sorbin, L.J. (1973) Histological Typing of Ovarian Tumors. In: World Health Organization International Histological Classification of Tumors, WHO, Geneva, 17-18.

[6] Krepart, G., Smith, J., Rutledge, F., et al. (1978) The Treatment for Dysgerminoma of the Ovary. Cancer, 41, 986-990. http://dx.doi.org/10.1002/1097-0142(197803)41:3<986::AID-CNCR2820410328>3.0.CO;2-P

[7] Vriesendorp, R., Aalders, J., Sleijfer, D., et al. (1984) Treatment of Malignant Germ Cell Tumors of the Ovary with Cisplatin, Vinblastine, and Bleomycin. Cancer Treatment Reports, 68, 779-781.

[8] Thomas, G., Dembo, A., Hacker, N., et al. (1987) Current Therapy for Dysgerminoma of the Ovary. Obstetrics Gynecology, 70, 268-275. 
Scientific Research Publishing (SCIRP) is one of the largest Open Access journal publishers. It is currently publishing more than 200 open access, online, peer-reviewed journals covering a wide range of academic disciplines. SCIRP serves the worldwide academic communities and contributes to the progress and application of science with its publication.

Other selected journals from SCIRP are listed as below. Submit your manuscript to us via either submit@scirp.org or Online Submission Portal.
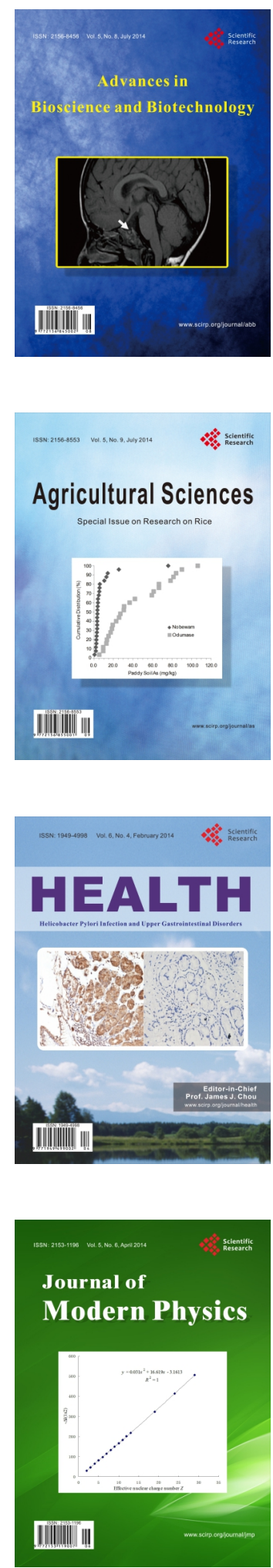
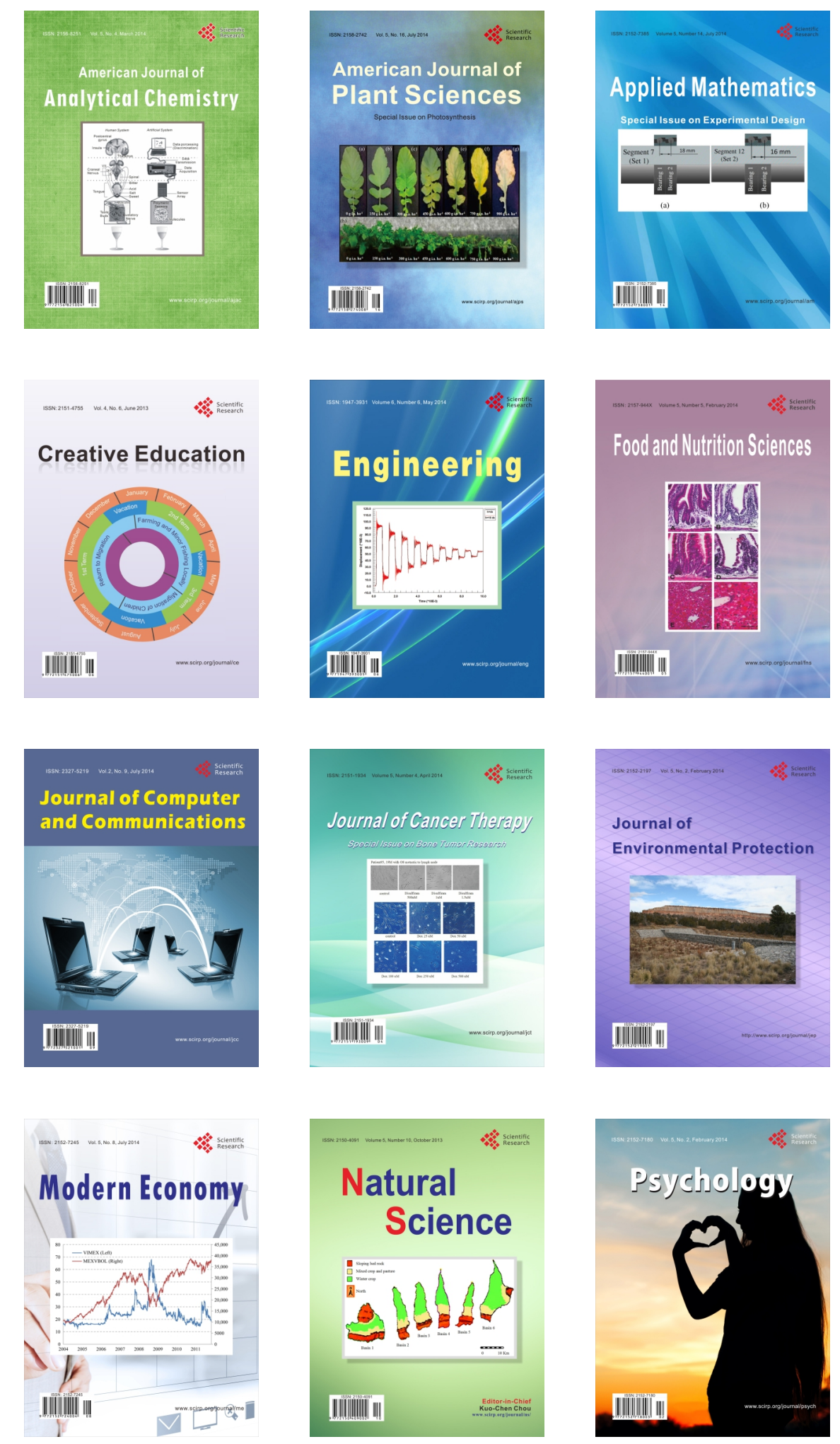